\title{
Archipel
}

ARCHIPEL Études interdisciplinaires sur le monde insulindien

$96 \mid 2018$

Varia

\section{Seminar Sejarah Nasional, Peringatan 60 tahun (1957-2017), Yogyakarta, Fakultas Ilmu Budaya, 14-16 Desember 2017}

Didi KWARTANADA, Ravando LIE et Yerry WIRAWAN

\section{(2) OpenEdition Journals}

Édition électronique

URL : http://journals.openedition.org/archipel/738

DOI : 10.4000/archipel.738

ISSN : 2104-3655

Éditeur

Association Archipel

\section{Édition imprimée}

Date de publication : 15 novembre 2018

Pagination : 3-8

ISBN : 978-2-910513-80-1

ISSN : 0044-8613

Référence électronique

Didi KWARTANADA, Ravando LIE et Yerry WIRAWAN, « Seminar Sejarah Nasional, Peringatan 60 tahun (1957-2017), Yogyakarta, Fakultas Ilmu Budaya, 14-16 Desember 2017 », Archipel [En ligne], 96 | 2018, mis en ligne le 20 novembre 2018, consulté le 21 décembre 2020. URL : http:// journals.openedition.org/archipel/738; DOI : https://doi.org/10.4000/archipel.738 


\section{ÉCHOS DE LA RECHERCHE}

\section{Seminar Sejarah Nasional, Peringatan 60 tahun (1957-2017), Yogyakarta, Fakultas Ilmu Budaya, 14-16 Desember 2017}

Seminar Sejarah Nasional yang diselenggarakan pada Desember 2017 di Fakultas Ilmu Budaya, Universitas Gajah Mada, Yogyakarta, merupakan peringatan 60 tahun Seminar Sejarah Nasional I yang diadakan tahun 1957. Seminar berjudul "Sejarah untuk Kebinekaan dan Ke-Indonesiaan: Refleksi 60 tahun Seminar Sejarah Indonesia, 1957-2017" ini merupakan kerjasama antara Departemen Sejarah, Fakultas Ilmu Budaya UGM, Direktorat Jenderal Kebudayaan, Kementerian Pendidikan dan Kebudayaan Republik Indonesia, Masyarakat Sejarawan Indonesia (MSI) dan Perkumpulan Prodi Sejarah Seluruh Indonesia (PPSI). Panitia kemudian membagi tema besar tersebut ke dalam empat sub-tema yang cukup luas, yaitu (1) Menemukan Historiografi Indonesia, (2) Pluralisme dan Identitas: Pengalaman dan Pandangan Berkebangsaan, (3) Agama dan Negara: Pergulatan Pemikiran dan Ketokohan, (4) Kapita Selekta Pendidikan Sejarah Indonesia.

Secara umum, dapat dikatakan seminar sejarah ini berhasil menarik perhatian sejumlah besar sejarawan. Hal itu terlihat dari banyaknya makalah yang dikirim. Menurut informasi panitia, yang diketuai oleh Dr. Sri Margana, mereka menerima kiriman 312 abstrak. Karena pertimbangan keterbatasan tempat dan waktu, panitia pun harus menyeleksi makalah-makalah tersebut menjadi 163 buah $^{1}$. Banyaknya jumlah peserta mengharuskan panitia

1. Prosiding dari seminar ini diterbitkan dalam empat jilid, yaitu Sri Margana, Retno Sekarningrum, Ahmad Faisol (ed.), Prosiding 60 Tahun Seminar Sejarah Nasional 19572017, Jilid 1: Menemukan Historiografi Indonesia Sentris, Yogyakarta, Komunitas Ombak, 2017; Sri Margana, Sri Utami Dewi Ningrum, Abmi Handayani (ed.), Prosiding 60 Tahun 
memperpanjang waktu seminar yang awalnya direncanakan dua hari menjadi tiga hari. Masing-masing hari berisi tiga hingga empat sesi, yang kemudian dipecah lagi ke dalam empat panel simultan, yang umumnya diisi oleh empat atau lima pemateri. Dengan penyusunan panel yang padat seperti ini, kami harus berbagi tugas agar bisa menghadiri panel-panel yang berlangsung bersamaan tersebut.

\section{Sejarah untuk Kebinekaan dan Keindonesiaan}

Pemilihan tema kebinekaan dan keindonesiaan sebagai tema utama dalam Seminar Sejarah Nasional 2017 penting untuk dicermati karena menunjukkan kepedulian sejarawan akan persoalan sejarah di Indonesia saat ini. Tidak hanya itu, pemilihan tema ini sekaligus menunjukkan pergeseran pokok perhatian para sejarawan Indonesia bila dibandingkan Seminar Sejarah I yang diselenggarakan 60 tahun sebelumnya di Universitas Gadjah Mada². Bila Seminar Sejarah I lebih menyoroti usaha penulisan sejarah nasional pascapenjajahan yang menekankan pada unsur nasionalisme ${ }^{3}$, maka dalam Seminar Sejarah Nasional 2017 ini, perhatian lebih difokuskan pada persoalan intoleransi dan anti-keberagaman yang belakangan marak terjadi di Indonesia. Seminar Nasional kali ini berusaha merespon persoalan tersebut dari sudut pandang sejarah. Penghargaan pada keberagaman dengan jelas dihadirkan dalam seminar ini bahkan tidak hanya dari tema tapi juga latar belakang peserta, pendekatan dan metode.

\section{Keberagaman Isi dan Peserta Seminar}

Keberagaman peserta dalam seminar sejarah sebenarnya bukan hal yang baru. Dalam Seminar Sejarah I tahun 1957, para pemateri yang hadir juga berasal dari beragam latar belakang ${ }^{4}$. Namun dalam seminar

\footnotetext{
Seminar Sejarah Nasional 1957-2017, Jilid 2: Pluralisme dan Identitas, Pengalaman dan Pandangan Kebangsaan, Yogyakarta, Komunitas Ombak, 2017; Sri Margana, Sri Utami Dewi Ningrum, Abmi Handayani (ed.), Prosiding 60 Tahun Seminar Sejarah Nasional 1957-2017, Jilid 3: Agama dan Negara di Indonesia, Pergulatan Pemikiran dan Ketokohan, Yogyakarta, Komunitas Ombak, 2017; Sri Margana, Baha'Udin, Ahmad Faisol (ed.), Prosiding 60 Tahun Seminar Sejarah Nasional 1957-2017, Jilid 4: Kapita Selekta (Pendidikan) Sejarah Indonesia, Yogyakarta, Komunitas Ombak, 2017.

2. Panitia Seminar Sejarah I tahun 1957 telah menerbitkan sejumlah buku antara lain Petundjuk Seminar Seminar Sejarah I (Yogyakarta, November 1957), Laporan Seminar Sedjarah (Yogyakarta, Januari 1958), Seminar Sedjarah, Acara I dan II (Yogyakarta, Juni 1958).

3. Tim yang bertugas menuliskan sejarah nasional gagal menyelesaikan tugasnya pada tahun 1963. Penulisan sejarah nasional dalam 6 jilid baru dimulai pada tahun 1970 (Nunus Supardi, Bianglala Budaya: Rekam Jejak 95 tahun Kongres Kebudayaan 1918-2013, Jakarta, Dirjen Kebudayaan Indonesia, 2013, hlm. 314-315).

4. Seminar Sejarah I diikuti oleh 11 peserta dengan beragam latar belakang membahas tematema: Periodisasi Sejarah Indonesia, Syarat Mengarang Kitab Sejarah Indonesia yang Bercorak Nasional, Pelajaran Sejarah Nasional di Sekolah, Pendidikan Ahli Sejarah, Pemeliharaan dan Penggunaan Bahan-bahan Sejarah.
} 
2017, keberagaman latar belakang pemateri semakin luas yang ditandai dengan terlibatnya sejumlah tokoh dari dunia seni seperti F.X. Harsono (seniman), Yuke Ardhiati (arsitek) maupun Mikke Susanto (kurator seni rupa). Keberagaman latar belakang peserta pada gilirannya menghadirkan bervariasinya tema dalam seminar ini. Berbagai kajian dan pendekatan baru juga turut memperkaya penulisan sejarah Indonesia. Tercatat beberapa panel dengan kajian dan pendekatan yang relatif baru di Indonesia seperti sejarah kesehatan, sejarah kuliner, olahraga, sejarah dan manfaat film bagi studi sejarah hingga sejarah seni.

Keberagaman tersebut juga hadir dalam bentuk pendekatan dan terobosan alternatif untuk penulisan sejarah Indonesia di masa depan salah satunya berkaitan dengan dunia digital. Kresno Brahmantyo misalkan yang menawarkan konsep "Sejarah Digital" untuk menjaga dan melestarikan sejarah Indonesia. Di samping itu, ada juga Amrullah Amir yang berupaya menghadirkan polemik sejarah antara Arung Palakka dan Sultan Hasanuddin di abad ke-16, ke era saat ini melalui analisis terhadap "perang" yang terjadi di media sosial terhadap penyematan titel 'pahlawan' atau 'pejuang' terhadap kedua sosok ini.

Tema tentang Islam menduduki tempat penting dalam seminar ini yang dikaji melalui berbagai perspektif, mulai dari pembahasan mengenai historiografi Islam yang disinggung oleh Jajat Burhanudin dalam naskahnya yang berjudul "Ulama dan Islam di Indonesia: Sejarah Kajian dan Kecenderungan Metodologis", persinggungan Islam dengan agama dan kepercayaan lain yang dibahas oleh Fitriati Harahap dalam naskahnya yang berjudul "Islam dan Kristen di Sipirok (Tapanuli Selatan) dalam Catatan Arkeologi dan Sejarah", Islam dan pluralisme seperti yang disinggung oleh Rahim Asyik F.A. dalam naskahnya membahas Jacobs-Affaire berupa Yahudi versus Islam di Tasikmalaya pada tahun 1936. Tema Islam dan Negara tercermin dalam naskah Slamat Trisila berjudul "Hegemoni Negara terhadap (Budaya) Islam di Bali pada Zaman Orde Baru", hingga pemikiran para tokoh Islam berpengaruh yang bisa dilihat dalam naskah Yasin Azhari berjudul "Imajinasi Nasionalisme Inklusif K.H. Ahmad Dahlan dalam Sejarah Indonesia." Sebaliknya, pembahasan sejarah yang terkait orang Kristen dan Katolik hadir secara khusus sekurangnya dalam dua panel di hari kedua dan ketiga yang antara lain Fransiska Widyawati dengan makalahnya bersama Yohanes S. Lon tentang masyarakat Katolik di NTT dan Muhammad Sairin dengan penelitian bersama Lukman Nadjamuddin mendiskusikan masyarakat Kristen di Poso.

Pemaparan tentang sejarah maritim, sebuah tema yang sangat terkait dengan pilihan pembangunan ekonomi pemerintah Jokowi saat ini, hadir sekurangnya dalam sebuah panel dengan pembicara Singgih Tri Sulistiyono yang membahas "Arah dan Perspektif Historiografi Maritim Indonesia". Dalam panel ini hadir pula Susanto Zuhdi yang mendiskusikan arah dan 
perspektif historiografi maritim Indonesia melalui sejarah Buton.

Periode Perang Dunia II, revolusi Indonesia dan periode sesudahnya masih mendapat perhatian mendalam dalam seminar ini dengan sebuah panel yang terdiri dari A.A. Bagus Wirawan bersama dengan A.A. Ayu Rai Wahyuni yang membahas tinjauan historiografis sejarah revolusi di Bali. Yang menarik dalam panel ini pembahasan tidak hanya dari sudut konsep Negara Kesatuan. Sebuah makalah yang disampaikan oleh Riska Anika Putri mengulas Pemerintahan Revolusioner Republik Indonesia (PRRI) berdasarkan koran Belanda.

Selain pembahasan penulisan sejarah yang bersifat nasionalis, pembahasan sejarah lokal cukup mendapat tempat dalam seminar 2017. Contohnya Tema keberagaman dalam sejarah pendidikan konteks lokal di Yogyakarta hadir dalam sebuah panel tersendiri yang terdiri dari Dwi Ratna Nurhajarini, Mutiah Amini, Baha'Udin, Asti Kurniawati. Selain itu, Abdul Karim membahas tentang pemerintahan Kerajaan Balanipa pada abad ke-16/17, Muslimin AR Effendy tentang Kesultanan Bima. Sayangnya dari sejumlah pemaparan tentang sejarah lokal, hanya ada satu yang mengulas Halmahera oleh Abdul Rahman dan tidak ada yang khusus membahas Papua.

Yang juga patut dicatat dalam seminar ini adalah pembahasan tentang sejarah perempuan hadir sekurangnya dalam dua panel di dua hari yang terpisah. Pada hari pertama Syarifah Aini membicarakan pemikiran Rohana Kudus. Sementara itu Widia Munira, Muhammad Akhyar dan Djono menulis tentang kepimpinan Ratu Safiatuddin di Aceh. Raisye S. Haghia mengulas tentang majalah Keoetamaan Isteri, Ita F. Nadia tentang "Identitas Perempuan Eksil". Pada hari kedua, sejarawan muda, Siti Utami Dewi mempresentasikan historiografi sejarah perempuan, dan Galuh Ambar Sasi tentang perempuan Yogyakarta pada masa Revolusi. Keduanya menunjukkan penguasaan literatur yang mendalam dan sama-sama sepakat bahwa persoalan saat ini bukan jumlah sejarawan perempuan, tetapi sensitivitas gender lebih penting bagi historiografi.

Panel tentang masyarakat Tionghoa juga hadir dalam seminar kali ini. Pada hari pertama Hendri Gunawan membahas secara singkat kajiannya tentang komunitas Tionghoa di Sulawesi Utara. Sementara itu, Yulianti menyampaikan hasil penelitiannya tentang keyakinan orang Tionghoa berdasarkan majalah Sam Kauw Gwat Po dan Moestika Dharma pada masa kolonial. Zeffry Alkatiri memaparkan hasil penelitiannya bersama Fuad Gani dan Reynaldo de Archelie tentang para pengusaha Tionghoa di Pontianak. Pemakalah lainnya yaitu Lukiyati Ningsih tentang orang Tionghoa di Kapasan, Surabaya. Di panel yang berbeda, Didi Kwartanada menyampaikan tentang kajian etnik Tionghoa pasca-1998. Tinjauan historiografis ini memberikan gambaran tentang tren perkembangan studi Tionghoa pada masa kini. Pada hari ketiga, sejarah masyarakat Tionghoa kembali hadir dalam pemaparan Dirga Fawakih tentang masyarakat tersebut di Tangerang. 
Di sisi lain kami juga mencatat tema-tema yang selama ini belum banyak mendapat tempat dalam penulisan sejarah nasional seperti peristiwa 1965, ternyata masih sangat minim pembahasannya dalam seminar ini. Salah satunya yang terkait dengan peristiwa tersebut hadir dalam pemaparan Satriono Priyo Utomo tentang Universitas Rakyat 1958-1965 dan Ita F. Nadia, seperti kami telah sebutkan di atas, membahas tentang identitas perempuan eksil. Namun yang menyegarkan kajian-kajian baru hadir dalam seminar ini disampaikan oleh dua sejarawan dari Universitas Padjadjaran, yaitu pemaparan Gani A. Jailani yang menyampaikan sejarah kedokteran di Indonesia dan Fadly Rahman tentang studi sejarah kuliner sebagai kajian historiografis. Kajian kuliner lainnya yang menarik untuk disebutkan di sini adalah pemaparan Ari Budiyanto tentang soto dan jejak kosmopolitanisme.

Pembahasan tentang seni dan olahraga juga turut hadir dalam seminar sejarah ini. Beberapa cabang seni yang terwakili adalah seni rupa melalui pemaparan Mikke Susanto tentang lukisan-lukisan koleksi Istana Kepresidenan RI dan Asikin Hasan tentang Gerakan Seni Rupa Baru. Sementara itu Yuke Ardhiati mengulas tentang historiografi arsitektur dan Danang Respati Puguh tentang seni pertunjukan Jawa. Kajian film dalam studi sejarah juga mendapat perhatian melalui pembahasan Aan Ratmanto dan Fandy Hutari yang masingmasing membicarakan tentang kegunaan film dokumenter sejarah sebagai medium alternatif historiografi dan sejarah film serta sandiwara di Indonesia. Yang tidak kalah menariknya adalah pemaparan RN Bayu Aji tentang penulisan sejarah olahraga.

Pada bagian akhir, kami ingin mengulas secara ringkas pemilihan periode berdasarkan judul-judul makalah yang dikirim untuk Seminar Sejarah Nasional ini (163 judul). Dapat dikatakan bahwa tema-tema yang diangkat mencakup hampir semua periode dalam penulisan sejarah di Indonesia. Di sini kami menyajikan sebuah tabel sederhana berdasarkan periode yang merangkum judul-judul dengan tema lintas periode atau yang tematis.

$\begin{array}{cc}\text { Klasik } & 4 \text { karya } \\ \text { Islam abad pertengahan } & 6 \text { karya } \\ \text { Periode abad ke-17-18 } & \text { Tidak ada } \\ \text { Abad ke-19 } & 1 \text { judul } \\ \text { Awal abad ke-20 } & 27 \text { judul } \\ \text { Jaman Jepang dan PD II } & 5 \text { judul } \\ \text { Jaman revolusi } & 5 \text { judul } \\ \text { Periode 1950an-1960an } & 2 \text { judul } \\ \text { Periode Orde Baru } & 11 \text { judul } \\ \text { Lintas Periode } & 43 \text { judul } \\ \text { Tanpa periode (tematis) } & 59 \text { judul }\end{array}$


Secara sepintas terlihat bahwa tema lintas periode mendominasi dengan 43 judul. Selanjutnya terdapat 27 judul untuk periode awal abad ke-20 dan tidak ada judul untuk periode VOC. Uniknya untuk periode Revolusi dan PascaPerang Kemerdekaan, yaitu 1950-an dan 1960-an, masing-masing hanya terdapat 5 dan 2 judul.

\section{Catatan Penutup}

Dari Seminar Sejarah Nasional tahun 2017 ini kita bisa memberikan setidaknya dua catatan penutup. Pertama, melihat dari jumlah abstrak dan pemakalah, seminar ini memperlihatkan tingginya semangat dan minat menulis sejarah, tidak hanya di antara sejarawan tapi juga kalangan non-sejarawan. Kenyataan ini merupakan tanda yang baik karena menunjukkan minat terhadap studi sejarah semakin luas dibandingkan tahun-tahun sebelumnya.

Kesimpulan kedua, seminar ini berhasil menunjukkan perkembangan terkini studi sejarah di Indonesia. Keberagaman tema dan metode terlihat sangat menonjol dalam pemaparan-pemaparan pemakalah yang sayangnya tidak semua tema menarik dapat kami ikuti karena keterbatasan waktu. Meskipun begitu terlihat jelas bahwa generasi muda sejarawan Indonesia masa kini telah melangkah jauh dibandingkan pendahulunya dalam menghadirkan tema-tema baru dan segar dalam penulisan sejarah. Hanya saja keberagaman tersebut terlihat seperti baru tahap hadir secara beragam tapi belum terkoneksi satu dengan yang lainnya. Studi-studi komparatif belum hadir dalam seminar kali ini. Artinya di sini, penulisan sejarah Indonesia yang lebih komprehensif masih harus menempuh jalan yang panjang. Meskipun begitu, bagi sejarawan Indonesia, kita dapat menyimpulkan bahwa keberagaman dan kekayaan bangsa dapat terus menjadi sumber inspirasi penulisan sejarah Indonesia dengan memperhatikan kesamaan dan memahami perbedaan-perbedaan kita sebagai sebuah bangsa.

DIDI KWARTANADA, RAVANDO LIE, YERRY WIRAWAN 